\title{
The Effect of Perception of Organizational Support, Organizational Culture and Servant Leadership on Employee Performance at the Office of the Regional Development Planning Agency (BAPPEDA) of the Mentawai Islands Regency
}

\author{
${ }^{1)}$ Taufik Hamidi, ${ }^{2)}$ Hendra Lukito \\ ${ }^{1)}$ Magister Management, Andalas University, Padang, Indonesia \\ ${ }^{2)}$ Magister Management Counsellor, Andalas University, Padang, Indonesia
}

\begin{abstract}
This research aims to determine and analyze the influence of Perception of Organizational Support, Organizational Culture and Servant Leadership on Employee Performance at the Office of the Regional Development Planning Agency (BAPPEDA) of the Mentawai Islands Regency. This research is exploratory research with quantitative method. Sampling technique with census, so sample size 84 employee. This research uses SPSS 16. This results of this research showed, perceptions of organizational support have positive and significant effect to employee performance, organizational culture have positive and significant effect to employee performance, and then servant leadership have positive and significant effect to employee performance.
\end{abstract}

Keywords:Perceptions Of Organizational Support, Organizational Culture, Servant Leadership and Employee Performance.

DOI: $10.7176 / \mathrm{EJBM} / 11-6-11$

\section{Introduction}

Nowadays in the administration of the state, civil servants in the government are referred to as bureaucratic machines. The main objective lies in the creation of good governance and making civil servants the center of attention that is quite serious because civil servants have a very important function. The need for reform towards the creation of civil servants who are more professional, skilled, open and oriented towards services to the community.

This implies that employee performance is an important factor in organizational life. Employee performance is a prerequisite and at the same time the basic capital to build organizational performance. But the current assessment of civil servants Both central and regional government organizations generally provide public services to meet community needs. This service is generally carried out by employees. But in reality, not all services provided by employees are adequate, in the sense that they are in accordance with the wishes, expectations or needs of the community.

Even though the government has been determined to carry out bureaucratic reform, there are still many complaints about the poor performance of civil servants. The same goes with the Office of the Regional Development Planning Agency (BAPPEDA) of the Mentawai Islands Regency. The things that always happened like the indications include, among others, that there are still complaints from the public about the services provided by employees, for example those related to lack of service in providing services, lack of response to problems faced by the community, impatience in helping people experiencing difficulties, inaction and lack of service delivery.

\section{Literature Review}

\section{Performance}

Basically the needs of human life are not only material, but also non-material such as self-pride and job satisfaction. The word performance has recently become a hot topic among entrepreneurs and administrators. Performance seems to be a valuable figure and has become the main goal of the organization / business entity, in addition to profit. Armstrong and Baron (1998) Performance is the result of work that has a strong relationship with the organization's strategic goals, customer satisfaction, and economic contribution (Wibowo, 2014).

\section{Perception of Organizational Support}

According to Fuller et al. (2012), Organizational support perception as an agreement on organizational support or concern for commitment. Eisenberger et al (2013) stated Perception of Organizational Support is related to organizational commitment to employees. If the organization is publicly related, employee dedication and loyalty to the company's commitment to the organization, then general employees also discuss the commitment that the organization asks them. Awards given by organizations can be considered to provide assistance to employees, such as those received, accepted, accepted, and promoted, obtain access to information, and other forms of assistance 
needed by employees to be able to use their work effectively. The following are the norms of reciprocity that cause employees and organizations to pay attention to the goals in the work.

\section{Organizational culture}

According to Gibson et al. (Sutanto, 2002) organizational culture is something that is trusted by employees and this trust can shape beliefs, values and expectations. Included in the definition of organizational culture are symbols, language, ideology, rituals, and myths; Scripts affect intellectual and financial success in the company. Mangkunegara (2012) suggested that providing a definition of organizational culture is a set of assumptions or systems of beliefs, values and norms developed in the organization that serve as guidelines for the behavior of its members to overcome external and internal adaptation problems.

\section{Servant Leadership}

Mc Cann et al (2014) defines Servant leadership as a new leadership model that puts service to others as a top priority. Servant leadership emphasizes increasing service to others, a holistic approach to work, increasing a sense of togetherness and sharing of contributions in decision making.According to Northouse, Richard et al (2017) Servant leadership is a leadership approach with altruistic nuances and strong ethics, requiring leaders to pay attention to their followers' needs and empathize with them. Leaders must take care of their followers by ensuring that they become healthier, wiser, free and independent, so that they can also become servant leaders.

\section{Review of Previous Research and Hypotheses}

Based on research by Arshadi et al (2013) examined the effect of Perception of Organizational Support on employee performance, indicating that, Perceived Organizational Support has an effect on performance. Other research conducted by Susmiati et.al (2015) which examined the effect of Perception of Organizational Support on performance, and the results of Perception of Organizational Support affect performance. Similar research was also conducted by Afzali et al. (2014) who examined the effect of Perception of Organizational Support on performance, and the results of Perception of Organizational Support had an effect on performance. Based on this research, hypothesis can be stated, namely:

\section{H1: Perception of Organization Support influences positively and significantly to employee performance}

The research conducted by Mursidta 2017, The Effect of Organizational Support Perception and Job Satisfaction on Employee Performance shows that, Perceived Organizational Support influences the performance of Organizational Support Perception significantly influences the performance of employees at PT Varia Usaha Beton Gresik, Then the research of Chiang et al (2012) which examined the effect of Perception of Organizational Support on performance, the result was Perception of Organizational Support influencing performance.

\section{H2: Organizational Culture positively and significantly to employee performance}

Rose et all (2008) research on multinational MNCs in 4 (four) countries (America, Europe, Japan and Malaysia) overall results show that American, Malaysian and European multinational companies have a significant relationship of organizational culture to organizational performance. The research conducted by Garini et all (2016) in PDAM companies also found that organizational culture influences employee performance. In a study conducted by Adewale and Anthonia (2013) entitled the influence of organizational culture on human resource practices: a study of selected private universities in Nigeria found that there was a close relationship between organizational culture and performance.

\section{H3: Servant Leadership positively and significantlyto employee performance}

Based on the research of Mc Cann et al (2014) 10 employees in hospitals in the United States found that Servant Leadership had an effect on Employee Performance. Then, in the research conducted by what was done by Richard et al. (2012) on hospitals found that servant leadership had an effect on Hospital Employee Performance. The research was also conducted by Harwiki (2015) about Servant Leadership to 40 Respondents of female workers in West Java Indonesia found that Servant Leadership can influence the employee performance, similar with research conducted by Melcar (2010) suggesting that Servant Leadership greatly influences organizational performance

\section{RESEARCH METHOD}

This research is a quantitative research in an explanatory form, where the problem solving model and analysis done using statistical analysist empirically examine the relationship between the research variables. The population in this study is Employee Performance at the Office of the Regional Development Planning Agency (BAPPEDA) of the Mentawai Islands Regency,amount in to 84 people.The sample use is all of the total population,which is 84 respondents. In analyzing the data, researchers used SPSS 16 application for windows to testing this research hypotesis with cover Multiple Regression analyse. 


\section{RESEARCH RESULTAND DISCUSSION}

\section{Respondents' Characteristics}

This research was conducted at Employees at the Office of the Regional Development Planning Agency (BAPPEDA) of the Mentawai Islands Regency. As respondents, the questionnaire was closed to be filled in directly. The questionnaire is confidential so it is expected to fill honestly and independentl, Of the 84 questionnaires that have been distributed, 84 respondents or all samples from Employees at the the Office of the Regional Development Planning Agency (BAPPEDA) of the Mentawai Islands Regency, responded to the questionnaire by filling in directly. Based on these data, it is known that the rate of respond rate in this study is $100 \%$. This proves that the respondents were very cooperative as the sample in this study.

Respondents who filled out the questionnaire were those who were male 58 people with a percentage of $69.0 \%$ and 26 or $31.0 \%$ of female respondents then they were Civil Servants with a percentage of 73.8 and $26.2 \%$ of respondents were Honor groups then respondents the work period of $<5$ years, which is as many as 23 people or $27.4 \%$ for $21-25$ years is the smallest respondents, namely 4 people or $6 \%$, those who have not married with a percentage of $27.4 \%$ and $78.6 \%$ of respondents respondents Married respondents the highest is in the salary group in the range of 3,000,000 - 5,000,000, which is as many as 37 people or $44 \%$, then $10,000,000-15,000,000$, which is the smallest respondent, namely 1 person or 1.2. most respondents were in the age group ranging from 26 to 35 years, namely as many as 29 people or $34.5 \%$. then followed 56 - 58 years, the smallest respondents were 9 people or $10.7 \%$, the most recent level of education data distribution was S1 / DIV education graduates totaling 63 people or $75 \%$ and the least education was D3 4 people or $4.8 \%$.

\section{Data Analysis and Hypothesis}

\section{Multiple Linear Regression Analysis}

From the three coefficient values on the independent variables above, it is obtained that the Organizational culture (X2) the largest value with a coefficient value of 0.501 or $50.1 \%$ while the smallest coefficient value is obtained by the Servant Leadership (X3) with a coefficient of 0.176 or $17.6 \%$. Based on these results it was found that the variable Organization Culture is the most dominant factor that influences Employee Performance then followed by the Perception Organizational Support variable with a coefficient of 0.249 or $24.9 \%$. while the Servant Leadership variable has the smallest influence compared to other independent variables that have an influence on Employee Performance.

Tabel 1. Multiple Linear Regression Analysis

\begin{tabular}{|l|l|l|}
\hline \multirow{2}{*}{ Variabel } & \multicolumn{2}{l}{ Unstandardized Coefficients } \\
\cline { 2 - 3 } & $\mathbf{B}$ & Std. Error \\
\hline (Constant) & 0.544 & .283 \\
\hline Perception of Organizational Support(X1) & 0.249 & .085 \\
\hline Organizational culture(X2) & 0.501 & .169 \\
\hline Servant Leadership (X3) & 0.176 & .164 \\
\hline
\end{tabular}

Source: The Result of SPSS Processing, 2019

\section{Coefficient of determination analysis}

Basically this test measures the extent of the ability of the model to explain variations in the dependent variable. The coefficient of determination is between zero and one. The small value of R2 means that the ability of the independent variable to explain the dependent variable is very limited. The testing in this study can be seen in the tabel below:

Tabel 2. R Square

\begin{tabular}{|l|l|}
\hline Adjusted R Square & Pengaruh Variabel Independent \\
\hline .666 & $66.6 \%$ \\
\hline
\end{tabular}

Source: Source: The Result of SPSS Processing, 2019

Based on the output, the adjusted R Square number is 0.666 or $66 \%$. This shows that the percentage of the contribution of the influence of the independent variables namely Perception of Social Support, Organizational Culture and Servant Leadership on Employee Performance is $66 \%$ or the variation of the independent variables used is able to explain $66 \%$ variation in the dependent variable. While the remaining $34 \%$ is influenced by other variables not included in this research model.

\section{Partial Test (t Test)}


$\mathrm{T}$ test is conducted to determine the significance of the influence of independent variables (Perception Organizational Support, Organizational Culture, Servant Leadership) partially or individually explain the dependent variable (Strategic Implementation). The results of the $t$ test can be seen in the following table 3:

Tabel 3. Partial Test (t)

\section{Coefficients ${ }^{\mathrm{a}}$}

\begin{tabular}{|c|c|c|c|c|c|}
\hline \multirow[t]{2}{*}{ Model } & \multicolumn{2}{|c|}{$\begin{array}{l}\text { Unstandardized } \\
\text { Coefficients }\end{array}$} & \multirow{2}{*}{$\begin{array}{l}\text { Standardiz } \\
\text { ed } \\
\text { Coefficient } \\
\text { S } \\
\text { Beta } \\
\end{array}$} & \multirow[t]{2}{*}{$\mathrm{T}$} & \multirow[t]{2}{*}{ Sig. } \\
\hline & B & Std. Error & & & \\
\hline \multirow{4}{*}{$\begin{array}{l}\text { Perception } \\
\text { Organzational Support } \\
\text { Organizational Culture } \\
\text { Servant Leadership }\end{array}$} & .544 & .283 & & 5.449 & .000 \\
\hline & .249 & .085 & .056 & 1.973 & .009 \\
\hline & .501 & .169 & .625 & 2.969 & .004 \\
\hline & .176 & .164 & .095 & 1.763 & .004 \\
\hline
\end{tabular}

By using the number of samples as many as 84 respondents, independent variables as many as 3 and (dependent variables) as many as 1 variable and the hypothesis is done in two directions, namely with a level of significant $95 \%(\alpha=5 \%)$.

\section{Discussion of the result of the research}

The Influences of Perceptions of Organizational Support to the Employee Performance

With the criteria for acceptance or rejection in this testing, a significance level of 0.05 and a significance value of 0,009 are used. T table is $1.670, \mathrm{H} 1$ is rejected if $\mathrm{T}$ counts $\leq \mathrm{T}$ table and is accepted if $\mathrm{T}$ count $>\mathrm{T}$ table. Based on the output from table 3 it can be seen that the value of T count $(1.973)>\mathrm{T}$ table $(1,670)$ then $\mathrm{H} 1$ is accepted, meaning that Perceptions of Organizational Support has a positive and significant effect on Employee Performance.

\section{The Influences of Organizational Culture to the Employee Performanc}

The second thing that can be done to test the hypothesis is by determining the level of significance in which the level of significance set in this study is 0.05 . and a significance value of 0.004 Then determine the $\mathrm{T}$ count of 2.696. The next step the researcher will compare $\mathrm{T}$ count with $\mathrm{T}$ table and the $\mathrm{T}$ value of the table taken is 1.670 . $\mathrm{T}$ count (2.696)> T table (1.670) then $\mathrm{H} 2$ can be accepted, meaning that the variable means that Organizational Culture has a positive and significant effect on Employee Performance.

\section{The Influences of Servant Leadership to the Employee Performance}

The second thing that can be done to test the hypothesis is by determining the level of significance in which the level of significance set in this study is 0.05 . and a significance value of 0.004 Then determine $\mathrm{T}$ count of 1.763 . The next step the researcher will compare $\mathrm{T}$ count with $\mathrm{T}$ table and the $\mathrm{T}$ value of the table taken is 1.670 . T count $(1.763)>\mathrm{T}$ table $(1,670)$ then $\mathrm{H} 3$ can be accepted, meaning that the variable means that Servant Leadership has a positive and significant effect on Employee Performance.

\section{CONCLUSION}

This research is based on previous research regarding the influence of perceptions of organizational support, organizational culture, and servant leadership on employee performance. This study uses a questionnaire as a primary data source. The questionnaire was distributed to 84 PNS respondents at the Office of the Regional Development Planning Agency (BAPPEDA) of the Mentawai Islands Regency. concluded that:

a. From the average respondent's answers we can see that perceptions of organizational support have a positive and significant influence on employee performance. The Office of the Regional Development Planning Agency (BAPPEDA) of the Mentawai Islands Regency must provide support in all matters to employees so that they feel that they are part of the service, for example, fulfilling both moral and material needs for employees and negotiations, so that they support everything 
b. On the other hand, organizational culture has the greatest influence on employee performance. The Office of the Regional Development Planning Agency (BAPPEDA) of the Mentawai Islands Regency must continue to maintain the existing cultural culture, but must continue to strive to develop and improve a variety of cultures that are able to better support employee performance.

c In addition to these two variables, there is one variable that also affects employee performance, namely servant leadership. The Office of the Regional Development Planning Agency (BAPPEDA) of the Mentawai Islands Regency, in working, with leaders who are close to employees, being able to communicate with employees well will certainly make employees want to continue to have good and maximum performance

\section{BIBLIOGRAPHY}

Adewale, O.O., Anthonia, A.A., (2013) Impact of Organizational Culture on Human Resource Practices : A Study of Selected Nigerian Private Universities. Journal of Competitiveness. Vol. 5, Issue 4, pp. 115-133, December 2013.

Anghelache, V. (2015). A Possible Explanatory Model for the Relationship between Teaching Motivation and Job Satisfaction. Procedia-Social and Behavioral Sciences, 180, 235-240.

Arokiasamy, A. R. A., Abdullah, A. G. K., Ahmad, M. Z., \& Ismail, A. (2016).

Transformational Leadership of School Principals and Organizational Health of Primary School Teachers in Malaysia. Procedia-Social and Behavioral Sciences, 229, 151-157.

Ali, Eko Maulana. 2012. Kepemimpinan Transformasional dalam Birokrasi

Pemerintahan. PT. Multicerdas Publishing.

Ali, N. N. K., Tang, S. Y. 2016. Does Multiple Leadership Styles Mediated by Job Satisfaction Inluence Better Business Performance? Perception of MNC Employees in Malaysia. SHS Web of Conference EDP Science. 2016 .

Baron, R. A dan Donn Byrne. 2003. Psikologi Sosial. Jakarta: Erlangga.

Birasnav, M., Rangnekar, S., \& Dalpati, A. (2010). Transformational leadership, interim leadership, and employee human capital benefits: an empirical study. Procedia-Social and Behavioral Sciences, 5, 1037-1042.

Belias, K., Koustelios, A. (2014). Transformational Leadership and Job Satisfaction in the Banking Sector: A Review. International Review of Management an Marketing. Vol. 4, No. 3, 2014, pp.187-200

Bowditch, James L., Buono, Anthony. 2007. A Primer on Organizational

Behavior, New York : John Wiley \& Son, Inc.

Jack Thomas McCann, Daniel Graves \& Lieven Cox Servant Leadership, Employee Satisfaction, andOrganizational Performance in Rural Community Hospitals Internationa Journal of Business and Management; Vol. 9, No. 10; 2014 ISSN 1833-3850 E-ISSN 1833-8119

Cetin, M. O., \& Kinik, F. S. F. (2015). An analysis of academic leadership behavior from the perspective of transformational leadership. Procedia-Social and Behavioral Sciences, 207, 519-527.

Chi, H-K.,Yeh, H-R., Yu, C-H. (2008.). The Effects of Transformation Leadership, Organizational Culture, Job Satisfaction on the Organizational Performance in the Non-profit Organizations. The Journal of Global Business Management, Vol.4(1), 129-137

Dessler, Gary. (2013). Manajemen Sumber Daya Manusia Jilid 1 Edisi Kesembilan.Jakarta: PT Indeks.

Donnelly, Gibson. 1996. Organisasi, Prilaku, Struktur, Proses. Jakarta: Erlangga 
Eisenberger, R., Armeli, S., Rexwinkel, B., Lynch, P. D., \& Rhoades, L. (2001). Reciprocation of Perceived Organizational Support. Journal of Applied Psychology, 86, 42-51. doi: 10.1037/0021-9010.86.1.42

Eisenberger, R., Cotterell, N., \& Marvel, J. (1987). Reciprocation Ideology. Journal of Personality and Social Psychology, 53, 743-750. doi: 10.1037/0022-3514.53.4.743

Eisenberger, R., Cummings, J., Armeli, S., Lynch, P. (1997). Perceived Organizational Support, Discretionary Treatment, And Job Satisfaction. Journal of Applied Psychology, 82, 812-820. doi: 10.1037/0021-9010.82.5.812

Eisenberger, R., Huntington, R., Hutchison, S., \& Sowa, D. (1986). Perceived Organizational Support. Journal Of Applied Psychology, 71, 500-507. doi: 10.1037/0021-9010.71.3.500

Eisenberger, R., Karagonlar, G., Stinglhamber, F., Neves, P., Becker, T. E., Gonzalez-Morales, M., \& SteigerMueller, M. (2010). Leader-Member Exchange And Affective Organizational Commitment: The Contribution Of Supervisor's Organizational Embodiment. Journal of Applied Psychology, 95, 1085-1103. doi: 10.1037/a0020858

Eisenberger, R., Stinglhamber, F., Vandenberghe, C., Sucharski, I. L., \& Rhoades, L. (2002). Perceived Supervisor Support: Contributions To Perceived Organizational Support And Employee Retention. Journal of Applied Psychology, 87, 565-573. doi: 10.1037/0021-9010.87.3.565

García-Guiu, C., Moya, M., Molero, F., \& Moriano, J. A. (2016).

Transformational leadership and group potency in small military units: The

mediating role of group identification and cohesion. Revista de Psicología del Trabajo y de las Organizaciones, $32(3), 145-152$.

Gibson, James L, et.al.(2012). Organizations: Behavior, structure, Processes.

14th ed. Boston, Mass: McGraw- Hill/Irwin.

Gomes, Faustino Cardoso. 2003. Manajemen Sumber Daya Manusia. Yogyakarta: CV Andi Offset

Ghozali, Imam. (2014). Aplikasi Analisis Multivariate dengan Program SPSS Edisi Ketujuh. Semarang.

Gözükara, İ., \& Şimşek, O. F. (2015). Linking transformational leadership to work engagement and the mediator effect of job autonomy: A study in a Turkish private non-profit university. Procedia-Social and Behavioral Sciences, 195, 963-971.

Güngör, P. (2011). The relationship between reward management system and employee performance with the mediating role of motivation: A quantitative

Hair et al. (2010). Multivariate Data Analysis, Seventh Edition. Pearson Prentice Hall

Hulin, C. L., dan Judge, T. A. 2003. Job attitudes: A theoretical and empirical review. Dalam W. C. Borman, D. R. Ilgen, \& R. J. Klimoski (Eds.), Handbook of psychology (Vol. 12, pp. 255-276). Hoboken, NJ: Wiley.

Hitka, M., \& Balážová, Ž. (2015). Comparison of motivation level of service sector employees in the regions of Slovakia and Austria. Procedia Economics and Finance, 23, 348-355.

Jayaweera, T. (2015). Impact of work environmental factors on job performance, mediating role of work motivation: A study of hotel sector in England. International journal of business and management, 10(3), 271.

Idris, M., Troena, E. A., Noermijati, Rohman, F., Newcombe, P. A. 2014. The Effects of Transformational Leadership Styles, Organizational Culture and Work Motivation on Employee Performance. International Journal of Business and Management Invention: Vol.3 Issue 3 March. 2014

Koesmono. (2005). Pengaruh Budaya Organisasi Terhadap Motivasi dan Kepuasan Kerja Serta Kinerja Karyawan : Jurnal Manajemen dan Kewirausahaan, vol7, no.2, September 2005:171-188

Luthans, Fred. 2006. Organizational Behavior. New York : Mc Graw-Hill. 
Lynch, P. D., Eisenberger, R., \& Armeli, S. (1999). Perceived organizational support: Inferior-versus-superior performance by wary employees. Journal of Applied Psychology, 84: 467-483. doi: 10.1037/0021-9010.84.4.46

Maharani, V., Troena, E. A., Noermijati. 2013. Organizational Citizenship Behavior Role in Mediating the Effect of Transformational Leadership, Job Satisfaction on Empoyee Performance : Studies in PT. Bank Syariah Mandiri Malang East Java. International Journal of business and Management: Vol. 8 No. 17; 2013

Mas`ud, Fuad. (2004). Survai Diagnosis Organisasi : Konsep dan aplikasi. Universitas Diponegoro.

Mangkunegara, A. A, Anwar Prabu,2011. Manajemen Sumber Daya Manusia

Perusahaan, Bandung: Remaja Rosdakarya.

Monecke, Armin dan Friedrich Leisch. 2012. SEM PLS: Structural Equation Modeling Using Partial Least Squares. Journal of Statistical Software, Volume 48, Issue 3, p. 1-32.

Munir, R. I. S., Rahman, R. A., Malik, A. A, Ma'amor, H. 2014. Relationship between Transformational Leadership and Employees' Job Satisfaction among the Academic Staff. International Congress on Interdisciplinar Business and Social Science: 2012.

Ouyang, Y, Hao, C-C, Jung, H-C. (2009). A Study on the Casual Relationships between Guanxi Networks and Job Performance of Banking Service Personnel. Problems and Perspectives in Management: Vol.7, Issue 4; 2009

Hitka, M., \& Balážová, Ž. (2015). Comparison of motivation level of service sector employees in the regions of Slovakia and Austria. Procedia Economics and Finance, 23, 348-355.

Jayaweera, T. (2015). Impact of work environmental factors on job performance, mediating role of work motivation: A study of hotel sector in England. International journal of business and management, 10(3), 271.

Paracha, M. U, Qamar, A., Mirza, A., Hassan, I. U., Waqas, H. (2012). Impact of Leadership Style (Transformational \& Transactional Leadership) on Emloyee Performance \& Meadiating Role of Job Satisfaction Study of Private School (Educator) in Pakistan, Global Journal of Management and Business Research. Vol. 12 issue 4 Version 1.0 March 2012.

Renyowijoyo, Muindro (2003). Hubungan Antara Budaya Organisasi,Komitmen Organisasi, Kepuasan Kerja,dan Prestasi Kerja Karyawan. Tesis tidak diterbitkan. Universitas Utara Malaysia

Richard W. Schwartz,MD, MBA; Thomas F. Tumblin, PhD (2012) The Power of Servant Leadership to Transform Health Care Organizations for the 21st-Century Economy From the Office of Clinical Operations, Veterans Affairs Medical Center, the Department of Surgery, College of Medicine, the Chancellor's Office, Chandler Medical Center, and the Center for Health Services Management and Research, University of Kentucky, Lexington (Dr Schwartz); and Asbury Theological Seminary, Wilmore, Ky (Dr Tumblin).

Rhoades, L., \& Eisenberger, R. (2002). Perceived organizational support: A review of the literature. Journal of Applied Psychology, 87, 698-714. doi: 10.2307/1556364

Rhoades, L., \& Eisenberger, R. (2002). Perceived organizational support: A review of the literature. Journal of Applied Psychology, 87, 698-714. doi: 10.2307/1556364

Rivai, Harif Amali. 2007. Dampak Organizational Justice dan Perilaku Kepemimpinan Transformasional terhadap Kepuasan Kerja Karyawan Jurnal Manajemen Universitas Bung Hatta. Vol. 2 No.1, Januari. 2007

Rivai, Veithzal. 2011. Manajemen Sumber Daya Manusiauntuk Perusahaan: dari Teori ke Praktik, Jakarta : Raja Grafindo Persada.

Robbins, Stephen P dan Jedge, Timothy A. 2011. Organizational Behavior. Fourteenth Edition. USA : Pearson Education, Inc. 
Robbins Stephen P. 2006. Perilaku Organisasi Edisi ke 10. PT. Indeks, Jakarta

Schermerhorn, 2005, Management 8th ed, John Wiley \& Sons, Inc, USA.

Sekaran, Uma. (2015). Research Methods For Business Edisi 4, jilid 1\& 2. Jakarta: Salemba Empat.

Sekaran, U., \& Bougie, R. (2010). Research Method for Business, A Skill Building Approach. John Wiley \& Sons Inc.

Sewang, Anwar. 2016. The Influence of Leadership Style, Organizaional Culture, and Motivation on the Job Satisfaction ang Lecturer's Performance at College of Darud Dakwah Wal Irsyad (DDI) at West Sulawesi. International Journal of Management and Administrative Sciences (IJMAS): Vol.3 No. 05.

Shoss, M. K., Eisenberger, R., Restubog, S. L. D., Zagenczyk, T. J. (2013). Blaming The Organization For Abusive Supervision: The Roles Of Perceived Organizational Support And Supervisor's Organizational Embodiment. Journal of Applied Psychology of Applied Psychology, 90, 698-714. doi: 10.2307/1556364

Shanock, S., \& Eisenberger, R. (2006). When supervisors feel supported: Relationships with subordinates' perceived supervisor support, perceived organizational support and performance. Journal of Applied Psychology, 91, 689-695. doi: 10.1037/0021-9010.91.3.689

Siagian, S.P. (2004). Manajemen Sumber Daya Manusia. Bumi Aksara : JakartaWibowo. 2012. Manajemen Kinerja. Edisi Ketiga. Jakarta: Rajawali Pers.

Sugiyono. 2014. Metode Penelitian Pendidikan Pendekatan Kuantitatif, Kualitatif dan R\&D, Bandung : Alfabeta.

Wibowo. 2012. Manajemen Kinerja. Edisi Ketiga, Jakarta : Rajawali Pers.

Winardi, J. 2007. Manajemen Perilaku Organisasi,Edisi Revisi Cetakan Pertama, Prenada Media, Jakarta.

Titisari, P. (2013). Culture and its impact and its impact on the working performance of government staff through job satisfaction.

Tsui, A. S., Pearce, J. L., Porter, L. W., \& Tripoli, A. M. (1997). Alternative approaches to the employeeorganization relationship: Does investment in employees pay off?. Academy of Management journal, 40(5), 10891121.

Wibowo (2014) Manajemen Kinerja. Jakarta: Rajawali

Yukl, Gary A.2005. Kepemimpinan Dalam Organisasi, edisi kelima. Jakata: PT INDEKS. 